Table 2. Mean percentages of leaves retained by Chinese, English, and two selections of Burford hollies after 3 or 8 days of exposure to ethylene.

\begin{tabular}{ccccr}
\hline \hline \multirow{2}{*}{$\begin{array}{l}\text { Ethylene } \\
\text { concn (ppm) }\end{array}$} & $\begin{array}{c}\text { Holly type } \\
\text { Burford } \\
\text { (spineless) }\end{array}$ & $\begin{array}{l}\text { Burford } \\
\text { (spiny) }\end{array}$ & Chinese & English \\
\hline & & Three-day exposure & & \\
0 & 100 & 100 & 100 & 100 \\
0.6 & 71 & 100 & 13 & 18 \\
15 & 96 & 95 & 0 & 0 \\
120 & 93 & 100 & 5 & 7 \\
& & Eight-day exposure & & 100 \\
0 & 100 & 100 & 96 & 10 \\
0.6 & 67 & 100 & 2 & 0 \\
15 & 38 & 92 & 0 & 7 \\
120 & 44 & 100 & 0 & \\
\hline \hline
\end{tabular}

this problem. Commercial use of STS would require care to avoid stimulation of abscission due to excess $\mathrm{Ag}^{+}$. A level of $\approx 1 \mu \mathrm{mol}$ per branchlet appears to be a practical treatment target.

The variability in the response to $\mathrm{C}_{2} \mathrm{H}_{4}$ of closely related holly cultivars (Burford holly is a cultivar of Chinese holly) is particularly interesting because it indicates the potential, at least in this species, of breeding for $\mathrm{C}_{2} \mathrm{H}_{4}$ resistance. tus. HortScience 16:761-762.

Cameron, A.C. and M.S. Reid. 1983. Use of silver thiosulfate to prevent flower abscission from potted plants. Scientia Hort. 19:373-378.

Gavinlertvatana, P., P.E. Read, and H.F. Wilkins. 1980. Control of ethylene synthesis and action by silver nitrate and rhizobitoxine in petunia leaf sections cultured in vitro. J. Amer. Soc. Hort. Sci. 105:304-307.

Mor, Y., A. H. Halevy, A.M. Kofranek, and M.S. Reid. 1984a. Postharvest handling of lily of the Nile flowers. J. Amer. Soc. Hort. Sci. 109:494497.

Mor, Y., M.S. Reid, and A.M. Kofranck. 1984b. Pulse treatments with silver thiosulfate and sucrose improve the vase life of sweet peas. J. Amer. Soc. Hort. Sci. 109:866-868.

Reid, M.S. 1985. Ethylene and abscission. HortScience 20:45-50.

Reid, M.S. and D.S. Farnham. 1980. Methods for preparing and using the STS complex. U.C. Flower and Nursery Rpt. Spring 1980. p. 6-7. Roberts, A.N. and R.L. Ticknor. 1970. Commercial production of English holly in the $\mathrm{Pa}$ cific Northwest. Amer. Hort. Msg. 49:301-314.

Sherman, M. 1985. Control of ethylene in the postharvest environment. HortScience 20:57-60.

Veen, H. and S.C. van de Geijn. 1978. Mobility and ionic form of silver as related to longevity of cut carnations. Planta 140:93-96.

\section{Controlled Atmosphere Effects on Physical Changes and Ethylene Evolution in Harvested Okra}

\author{
Lawford Baxter ${ }^{1}$ and Luther Waters, Jr. ${ }^{2}$ \\ Department of Horticultural Science and Landscape Architecture, \\ University of Minnesota, St. Paul, MN 55108
}

Additional index words. Abelmoschus esculentus, mucilage viscosity, storage, toughness, fibrousness, total solids

\begin{abstract}
Pods of okra (Abelmoschus esculentus L. Moench) stored in an atmosphere of $5 \% \mathrm{O}_{2}$ and $10 \% \mathrm{CO}_{2}$ at $10 \pm 1 \mathrm{C}$ were compared with pods stored in air at the same temperature to determine the effects of storage environment on physical characteristics and ethylene evolution of the pods. Controlled-atmosphere- (CA) stored pods lost less weight, retained total solids and chlorophyll better, and had a higher mucilage viscosity than air-stored pods. Toughness, fibrousness, and incidence of microbial decay were lower in CA-stored pods than in air-stored pods. No differences were seen in the levels of alcohol-insoluble solids or discoloration of the cut surface between pods from the two storage environments. Ethylene evolution was lower in CA- than airstored pods.
\end{abstract}

Fresh okra is a popular ingredient of soups and stews where a highly viscous consis-

Received for publication 20 May 1988. Paper no. 15982 of the Scientific Journal Series, Univ. of Minnesota Agricultural Experiment Station. The cost of publishing this paper was defrayed in part by the payment of page charges. Under postal regulations, this paper therefore must be hereby marked advertisement solely to indicate this fact.

'Graduate Student. Current address: Hercules Inc. Research Center, Wilmington, DE 19894.

${ }^{2}$ Professor. tency is desired, In addition to its being a good source of a viscous mucilage, okra also provides fiber and protein (9) and vitamin C (1) in the diet. Fresh okra has a high respiration rate and is extremely perishable (8). Quality loss in harvested okra is usally manifested as shriveling, toughening, and chlorophyll degradation (16). These conditions detract from the appearance of the pods, leading to rejection by consumers, even if nutritional quality was not affected adversely.

Spraying fresh okra with potassium phos- phate (11) and cycocel (16) has been found effective in reducing postharvest loss, but only under experimental conditions. Modified-atmosphere (MA) storage has been effective in extending storage life (3) and ameliorating chilling injury (10) of okra, but there is little information concerning the effects of modification of the storage atmosphere on fresh okra quality. The objective of this study was to determine the effects of controlled-atmosphere (CA) storage on physical characteristics and ethylene evolution in okra.

'Clemson spineless' Okra was grown on the St, Paul campus of the Univ. of Minnesota under commercial conditions. Fruit were harvested 6 days after anthesis, trimmed, immediately forced-air-cooled (to $\approx 12 \mathrm{C}$ ) and placed in a $69 \times 37 \times 37-\mathrm{cm}(\mathrm{L} \times \mathrm{W} \times$ $\mathrm{H})$ plexiglass chamber that was then sealed. The recommended CA for okra, 5\% $0_{2}$ plus $10 \% \mathrm{CO}_{2}$, with the remainder $\mathrm{N}_{2}(12)$, was prepared by mixing commercially bottled gas from high-pressure cylinders and conducted into each chamber. A system of solenoid valves and timers controlled the flow of gas into the chambers to provide one complete change of the atmosphere about every $16 \mathrm{hr}$. Temperature was held at $11 \pm 1 \mathrm{C}$ and $90 \%$ to $93 \% \mathrm{RH}$. Pods stored at the same temperature and relative humidity were used as controls, which received one complete change of air about every $16 \mathrm{hr}$. Each test consisted of a single treatment and control chamber with three tests per year for 2 years.

To determine ethylene levels, a gas sample was withdrawn from each chamber at the start of storage and at 1-hr intervals for $8 \mathrm{hr}$ and then at 4-hr intervals for $16 \mathrm{hr}$ and ana- 


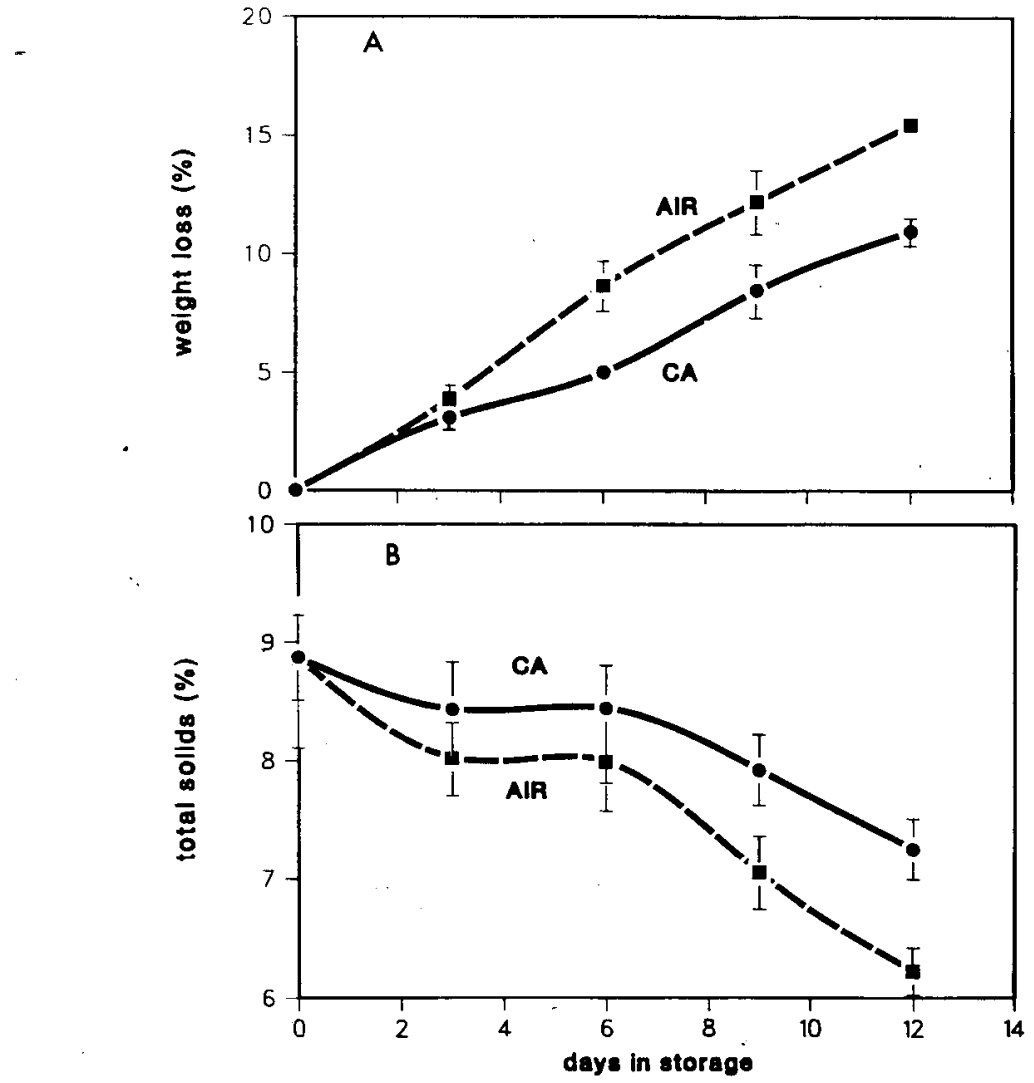

Fig. 1. Weight loss (fresh-weight basis)(A) and total solids content (B) of okra pods stored in 5\% $0_{2}+10 \%$ CO, or in air. Data points represent the means of six observations. Vertical bars represent \pm SE. Bars not shown when smaller than point markers.

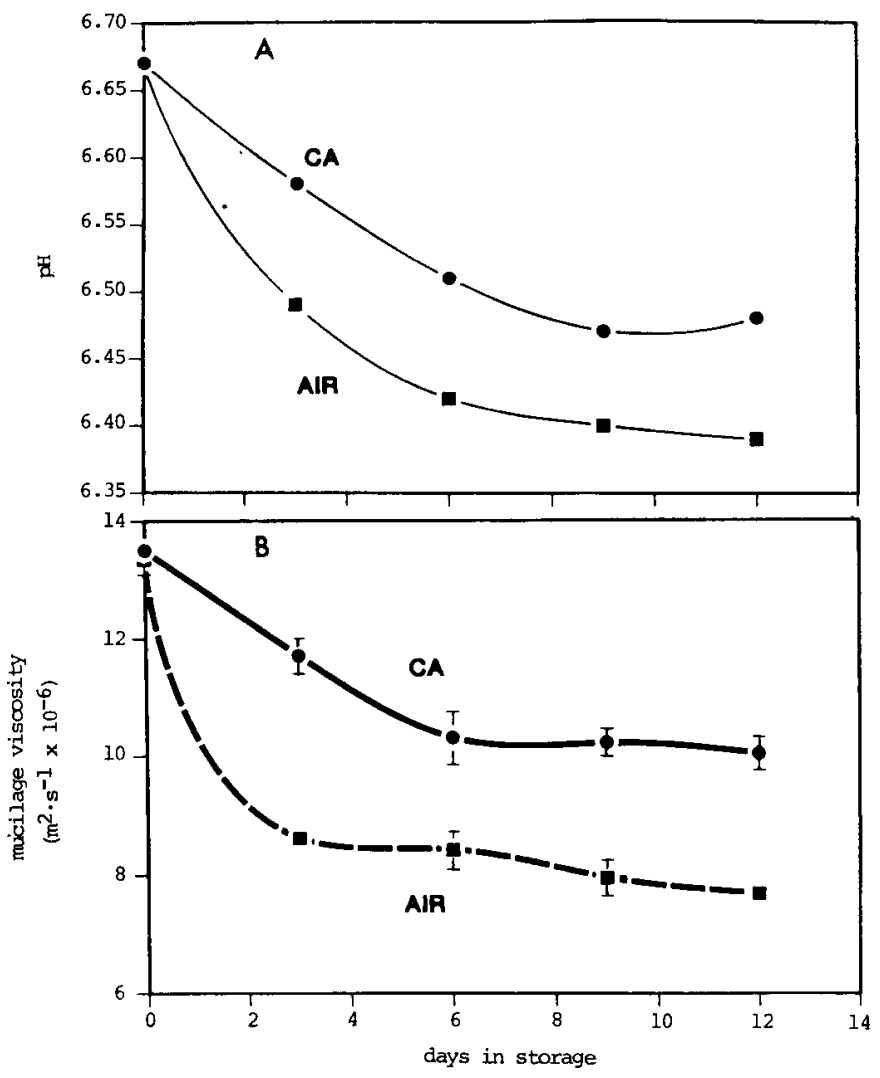

Fig. 2. Changes in $\mathrm{pH}(\mathbf{A})$ and mucilage viscosity (B) of okra pods stored in $5 \% \mathrm{O}_{2}+10 \% \mathrm{CO}_{2}$ or in air. Data points represent the means of six observations. Vertical bars represent $\mathrm{E}$. Bars not shown when smaller than point markers. lyzed on a Hewlet Packard 5880A gas chromatography fitted with a flame ionization detector. The $15-\mathrm{cm}$ stainless steel column was packed with 80-100 mesh Porapak Q (Suppelco, Bellefonte, Pa.). Ethylene analysis was terminated at $24 \mathrm{hr}$, i.e., after evolution of the gas leveled off.

Pods were removed from storage at 3-day intervals during 12 days and analyzed to determine the effects of storage environment on physical characteristics. Percent weight loss was determined by comparing the weight of three 120 -g samples at each sampling date to the weight of the same samples at the start of the study. Total solids were determined according to Scott and Kramer (15). Shear resistance was determined by measuring the force required to cut through three raw okra pods using an Instron Universal Testing Machine equipped with a 500-kg load cell, but using the asparagus cell and blade (20). The pods were placed horizontally in the cell and cut $3.0 \mathrm{~cm}$ from the base. Crosshead and chart speeds were $200 \mathrm{~mm} \cdot \mathrm{min}^{-1}$ and 500 $\mathrm{mm} \cdot \mathrm{min}^{-1}$, respectively. The crosshead speed chosen was most consistent in relating shear strength to pod maturity and quality (unpublished data). The maximum value on the force scale was taken as a measure of shear resistance.

Viscosity of the mucilage was determined by blending $100 \mathrm{~g}$ of whole okra pods with $200 \mathrm{ml}$ of double-distilled water for $5 \mathrm{~min}$. The $\mathrm{pH}$ of the homogenate was determined (Henna Instruments $\mathrm{pH}$ meter) before it was centrifuged for $30 \mathrm{~min}$ at $10,000 \mathrm{rpm}$, The viscosity of the supernatant then was measured using a Canon Fenske capillary viscometer (size 300) held in a 40C water bath. In addition, the viscosity of the crude mucilage extract was measured at $\mathrm{pH}$ values of $4,5,6,7,8,9$, and $10 \pm 0.05$ to determine $\mathrm{pH}$ effects on viscosity. Alcohol-insoluble solids content (AIS) was determined on 50g samples of the material (13) and chlorophyll content determined by a spectrophotometric method (18).

The degrees of microbial infestation and discoloration of the cut ends of all pods were rated on a visual scale where $0=$ pods free of defects and $5=$ unsalable pods. Alternaria spp. was identified as the major causal pathogen of diseased pods.

The experimental design was a randomized complete block (RCB) with three replications. Each replication consisted of $=1360$ $\mathrm{g}$ of uniformly sized fruits. The experiment was conducted during the 1986 growing seasons. Because the data from both years were similar, those for each characteristic were combined. The appropriate statistical analysis for an RCB design was performed on the data at each sampling. All values represent the means of six observations.

Weight loss and total solids. Controlledatmosphere-stored okra lost less weight and retained total solids better than pods stored in air (Fig. $1 \mathrm{~A}$ and B). Weight loss of okra stored in CA relative to that stored in air was similar to that for other commodities $(2,6)$. A presumed reduced respiration rate of pods under CA may have contributed to a greater 


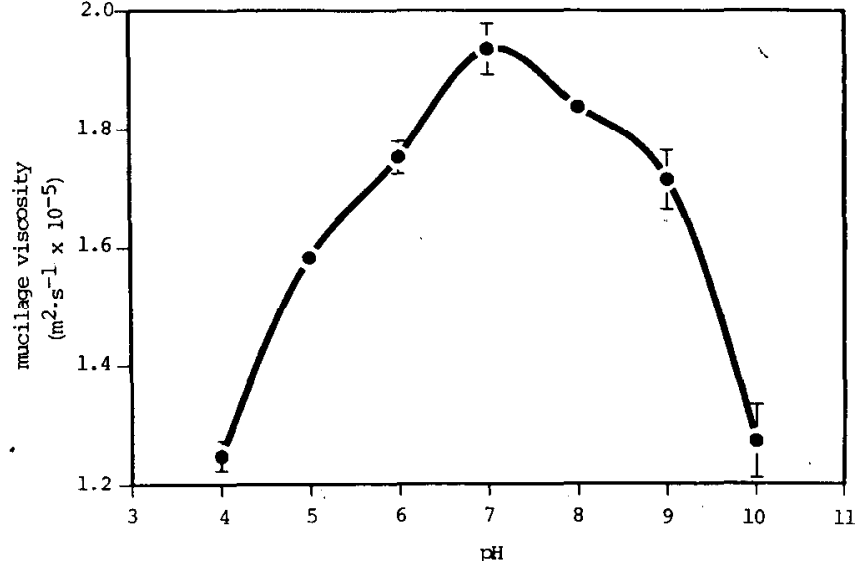

Fig. 3. Effect of $\mathrm{pH}$ on the viscosity of the crude mucilage extract of fresh okra pods. Vertical points represent \pm SE. Each point represents the mean of six observations.
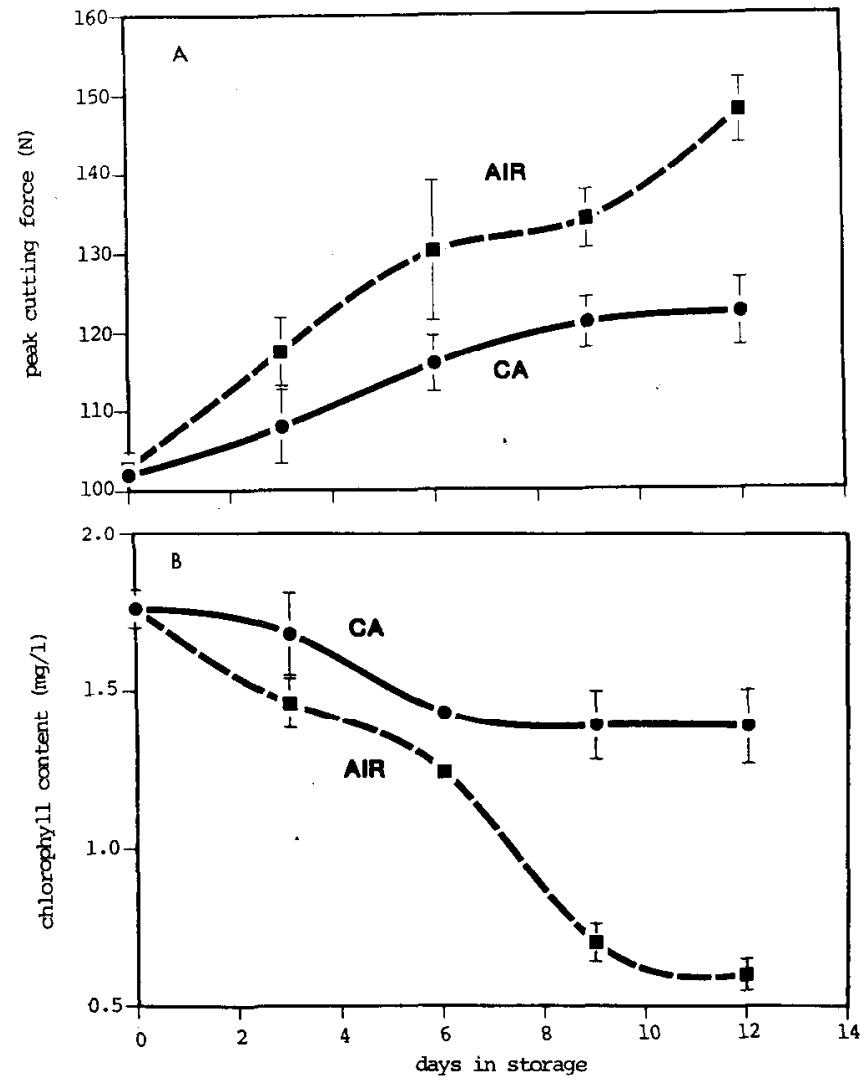

Fig. 4. Changes in peak cutting force (A) and chlorophyll content $(\mathbf{B})$ of okra pods stored in $5 \% \mathrm{O}$ $+10 \% \mathrm{CO}_{2}$ or in air. Points represents the means of six observations. Vertical bars represent \pm SE. Bars not shown when they are smaller than point markers.

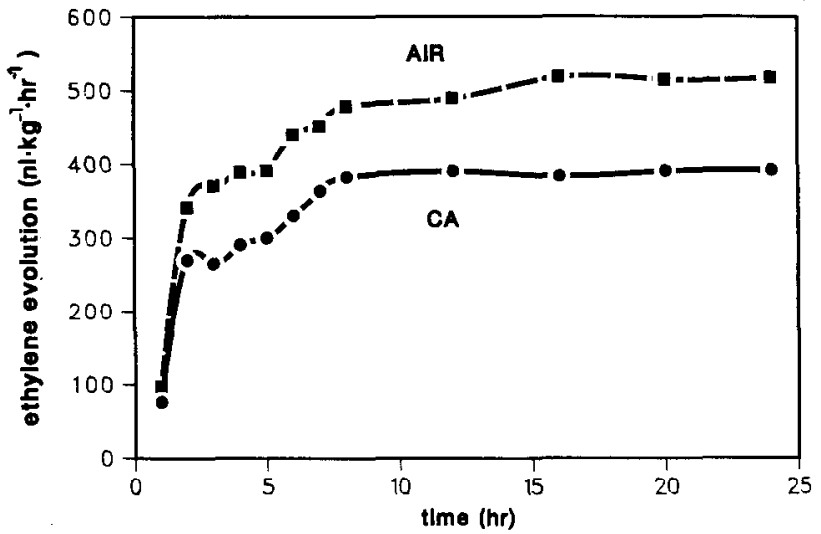

Fig. 5. Ethylene evolution of okra pods stored in 5\% $\mathrm{O}_{2}+10 \% \mathrm{CO}_{2}$ or in air. Points represent the means of six determinations. Vertical bars representinge are smaller than point markers and are not shown. retention of total solids (Fig. 1B) in these pods.

Disease development. Severe decay of pods by Alternaria likely played a role in weight loss. controlled-atmosphere-stored pods were much less affected by the pathogen than those kept in air, especially by days nine and 12 (data not shown). Alternaria rot of okra pods was characterized by a general decay and oozing of a brown, viscous substance. Controlled atmosphere has little direct effect on Alternaria and only $\mathrm{O}$ concentrations $<0.5 \%$ have been found to inhibit sporulation and mycelial growth of the pathogen (5). No reports were found concerning the effects of elevated $\mathrm{CO}_{2}$ levels on Alternaria development.

Viscosity and $p H$. The mucilage from CAstored pods was more viscous and had a higher $\mathrm{pH}$ than that from pods stored in air (Fig. 2 ). The ability of CA storage to maintain viscosity is important to okra quality. Many consumers have a strong preference for highly viscous pods because of the importance of okra as a thickener for soups and stews (4). The higher viscosity and $\mathrm{pH}$ of pods held in CA suggest a relationship between the two characteristics. This was confirmed by the $\mathrm{pH} \times$ viscosity study on the crude mucilage extract where the highest viscosities were obtained between pH 6 and 8 (Fig. 3). Although there was a decline in $\mathrm{pH}$ values for both CA- and air-stored pods (Fig. 2), the $\mathrm{pH}$ did not fall outside the range at which normal physiological functions occur.

Toughness. Toughness, expressed as shear resistance, was lower for CA-stored pods than those stored in air (Fig. 4A). Toughness is an important quality criterion of fresh okra because tough pods are inedible and have a lower mucilage content than tender ones (17). Conditions that contribute to toughness, such as fibrousness and Signification, are ethylene-mediated (7), and it is reasonable to conclude that the lower toughness of CA pods is a result of reduced ethylene evolution (Fig. 5).

Color of pods and discoloration of the cut ends. Chlorophyll retention was greater for CA- than air-stored pods (Fig. 4B). A bright green appearance is important to fresh okra quality because brown pods are rejected by consumers. The main benefit of CA storage of some green vegetables is the prevention of color loss due to inhibition of chlorophyll destruction (14) linked to ethylene activity (19). Brown discoloration of the cut ends of the pods occurred to the same extent under both storage conditions (data not shown).

\section{Literature Cited}

1. Achinewhu, S.C. 1983. Ascorbic acid content of some Nigerian local fruits and vegetables. Qual. Plant. 33:261-266.

2. Adamicki, F. and K.K. Kepka. 1977. Storage of cauliflower in CA and plastic bags. Acta Hort. 62:23-29.

3. Anandaswamy, B. 1963. Prepackaging studies on fresh produce. IV. Okra (Abelmoschus esculentus L. ). Food Sci. (Mysore) 12:332-335.

4. El-Mahdy. A.R. and L.A. El-Sebaiy. 1984. Preliminary studies on the mucilages ex- 
tracted from okra fruits, taro tubers, Jew's mellow leaves and fenugreek seeds. Food Chem. 14:237-249.

5. Follstad, M.N. 1966. Mycelial growth rate and sporulation of Alternaria tenuis, botrytis cinera, Claudosporium herbarum and Rhizopus stolinifer in low oxygen atmosphere. Phytopathology 36(9):1098-1099.

6. Geeson, J.D. and K.M. Browne. 1980. Controlled atmosphere storage of white winter cabbage. Ann. Applied Biol. 95:267-272.

7. Haard, N. F., S.C. Sharma, R. Woolfe, and C. Frenkel. 1974. Ethylene induced isoperoxidase changes during fiber formation in postharvest asparagus. J. Food Sci. 39:452456.

8. Hardenburg, R. E., A.E. Watada, and C.Y. Wang. 1986. The commercial storage of fruits, vegetables, and florists and nursery stocks. USDA Hdbk. 66

9. Ifon, E.T. and O. Bassir. 1980. The nutritive value of some Nigerian leafy green vegetables: 2. The distribution of protein, carbohydrates (including ethanol soluble simple sugars) crude fat, fiber and ash. Food Chem. 5:231-235.

10. Ilker, Y. and L.L. Morris. 1975. Alleviation of chilling injury of okra. Hortscience 103(30):324. (Abstr.)

11. Joshi, H.C., N. Joshi, N.C. Joshi, and P-C Pant. 1984. Storage life of okra. Sci. \& Culture 50:90-91.

12. Kader, A. A., R.F. Kasmire, F.G. Mitchell, M.S. Reid, N.F. Sommer, and J.F. Thompson. 1985. Postharvest technology of horticulture crops. Univ. of California, Davis. Spec. Publ. 3311:60.

13. Lee, F.A. 1943. Determination of toughness of frozen asparagus. Food Res. 8:249-253.

14. Lieberman, M. and R.E. Hardenberg. 1954. Effect of modified atmosphere on respiration and yellowing of broccoli at $75^{\circ} \mathrm{F}$. Proc. Amer. Soc. Hort. Sci. 63:409-414.

15. Scott, L.E. and A. Kramer. 1949. Physiological changes in asparagus after harvest.
Proc. Amer. Soc. Hort. Sci. 54:357-366,

16. Singh, B. P., D.K. Bhatnager, and O.P Gupta. 1978. Effect of growth retardants and wax emulsion on the shelf life of okra (Abelmoschus esculentus) (L. Moench. ) Haryana J. Hort. Sci. 7(1-2):91-94.

17. Tamura, J. and T. Minamide. 1984. Harvesting maturity, handling and storage of okra pods. Bul. Univ. Osaka. Pref. Ser. B. 36:8797.

18. Vernon, L.P. 1960. Spectrophotometric determination of chlorophylls and pheophytin in plant extracts. Anal. Chem. 32:1144-1150.

19. Wang, S. S., N.F. Haard, and G.R. Dimarco. 1971. Chlorophyll degradation in controlled atmosphere storage of asparagus. J. Food Sci. 36:657-661.

20. Wiley, R. C., N. Elehwany, A. Kramer, and F. J. Hager. 1956. The shear press-An instrument for measuring the quality of foods: IV. Application to asparagus. Food Technol. 8:439-443.

\title{
Paclobutrazol, Root Growth, Hydraulic Conductivity, and Nutrient Uptake of 'Nemaguard' Peach
}

\author{
Mark Rieger \\ Department of Horticulture, University of Georgia, Athens, GA 30602
}

Giancarlo Scalabrelli

Dipartimento di Coltivazione e Difesa delle Specie Legnose, Sezione

Coltivazioni Arboree, University di Pisa, Via del Borghetto 80, 51600

Piss, Italy

Additional index words. Prunus persica, PP333, Cultar, plant nutrition, rootstock

\begin{abstract}
Paclobutrazol (PBZ) was supplied in nutrient solution culture to 'Nemaguard' peach rootstock [Prunus persica $\times$ P. davidiana] at concentrations of $0,0.001$, $0.01,0.1$, and $1.0 \mathrm{mg} \cdot \operatorname{liter}^{-1}$. PBZ increased root : shoot ratio and decreased root length by $\approx 5$-fold over the range of $\mathrm{PBZ}$ concentrations tested. Root tip diameter, stele diameter, and width of the root cortex were not significantly affected by PBZ. Root hydraulic conductivity decreased log-linearly with increasing PBZ concentration; however, this decrease did not affect midday leaf conductance or net photosynthetic rate. Foliar levels of $\mathrm{N}, \mathrm{P}, \mathrm{K}, \mathrm{Fe}$, and Mo were reduced, whereas levels of $\mathrm{Ca}, \mathrm{Mg}, \mathrm{B}$, and Mn were increased by PBZ. The magnitude of changes in foliar nutrition were proportional to the degree of growth suppression. Chemical name used: $(2 R S, 3 R S)-l-(4-$ chlorophenyl)-4,4-dimethyl-2-(1H-1,2,4 -triazol-1-yl)pentan-3 -ol (paclobutrazol).
\end{abstract}

Paclobutrazol (PBZ) is a potent gibberellin synthesis inhibitor that effectively con-

Received for publication 27 Jan. 1989. A contribution of the Univ. of Georgia Agricultural Experiment Station, College Station, Athens. This research was supported by state and Hatch Act funds allocated to the Georgia Agricultural Experiment Stations and CNR NATO Fellowship (N.217.21.06) awarded to G.S. We thank Anita Harris, Gloria BeLvan, and Hazel Davis for technical assistance. The cost of publishing this paper was defrayed in part by the payment of page charges. Under postal regulations, this paper therefore must be hereby marked advertisement solely to indicate this fact. trols vegetative growth of fruit trees (Curry, 1988; Sanchez et al., 1988). PBZ can reduce the need for and costs associated with dormant-pruning (Sanchez et al., 1988; Stan et al., 1985) or summer-pruning (Martin et al., 1987), and is currently used on a limited basis in Australia and regions of Europe for this purpose (B. G. Lever, ICI Plant Protection Div., personal communication). However, several effects other than shoot growth suppression have been reported, including decreased leaf area and increased specific leaf weight (Early and Martin, 1988; Wood, 1984), alteration of fruit size and quality (Looney and McKellar, 1987; Martin et al., 1987; Shaltout et al., 1988), increased root : shoot ratio (Atkinson and Crisp, 1983; Early and Martin, 1988; Swietlik and Miller, 1983; Wang et al., 1985), and altered root growth and physiology (Atkinson and Crisp, 1983; Bausher and Yelenosky, 1986; Early and Martin, 1988; Steffens and Wang, 1984; Wang et al., 1985; Williamson et al., 1986).

Increased diameter and decreased length of young roots due to PBZ treatment has been reported for citrus (Bausher and Yelenosky, 1986) and peach (Williamson et al., 1986). Such morphological changes may influence water and nutrient uptake because these processes occur most actively in young, unsuberized roots (Atkinson, 1980). Furthermore, PBZ treatment may reduce drought avoidance of nonirrigated trees by decreasing the soil volume occupied by roots. The effects of PBZ on root hydraulic conductivity and nutrient uptake have not been studied in peach. The objective of this study was to determine the effect of paclobutrazol on root growth and morphology, root hydraulic conductivity, and nutrient uptake for 'Nemaguard' peach rootstock.

Terminal semihardwood cuttings of ' $\mathrm{Ne}$ maguard' peach rootstock were taken in Aug. 1987 and rooted as described by Couvillon and Erez (1980). Rooted cuttings were stored at $4.5 \mathrm{C}$ until June 1988 to satisfy chilling and prevent budbreak. Forty plants $\approx 20 \mathrm{~cm}$ tall and exhibiting uniform budbreak were selected and prepared for nutrient solution culture by washing vermiculite from roots and removing vegetation from the lower 6 $\mathrm{cm}$ of the stems. Four plants were placed into each of ten 14-liter containers filled with half-strength nutrient solution (Jones, 1985). Aeration and agitation of the solution was provided by a pressurized air line inserted at the bottom of each container. Plants were grown in a greenhouse with $90 \%$ transmission of solar radiant flux and a temperature regime of 25 to $35 \mathrm{C}$ day, 15 to $25 \mathrm{C}$ night. After a 3-day acclimation period, the halfstrength nutrient solution was replaced with full-strength solution to which PBZ was added 